\title{
Interviews with four Irish writers
}

\section{Bertrand Cardin}

\section{(2) OpenEdition \\ Journals}

\section{Electronic version}

URL: http://journals.openedition.org/etudesirlandaises/5778

DOI: 10.4000/etudesirlandaises. 5778

ISSN: 2259-8863

\section{Publisher}

Presses universitaires de Caen

\section{Printed version}

Date of publication: 18 December 2018

Number of pages: 111-128

ISBN: 978-2-7535-7693-3

ISSN: 0183-973X

\section{Electronic reference}

Bertrand Cardin, «Interviews with four Irish writers », Études irlandaises [Online], 43-2 | 2018, Online since 01 November 2018, connection on 13 September 2019. URL : http://journals.openedition.org/ etudesirlandaises/5778; DOI : 10.4000/etudesirlandaises.5778 


\title{
Interviews with four irish writers
}

\author{
Bertrand CARDIN \\ (Vernon, France, 8 April 2017)
}

\section{图 Introduction}

For several years, the Médiathèque — the multimedia library-in Vernon, Normandy (France) has been organizing a literary prize, 'Escapades', which is awarded every two years. The 2017 Prize is dedicated to Irish literature. Six recent novels, written by Irish writers, have been selected:

The Gamal by Ciarán Collins (2013),

Academy Street by Mary Costello (2014),

The Trout by Peter Cunningham (2016),

Ghost Moth by Michèle Forbes (2013),

Red Sky in Morning by Paul Lynch (2013),

The Thrill of it All by Joseph O'Connor (2014).

As these novels have been translated into French, they can be read by any French reader.

On $1^{\text {st }}$ October 2016, to launch the event, I was invited to give a lecture entitled "An Overview of Irish Literature" to an audience of about 200 people, in order to contextualize these novels in the wide field of Irish literature, and to show the readers how far the listed books are anchored in the Irish tradition. The library's readers, together with the local secondary school students, had six months to read the books and vote by secret ballot for their favorite one. At the end of this reading period, the prize was awarded on 8 April 2017 in the presence of four of the writers: Mary Costello, Michèle Forbes, Ciarán Collins and Paul Lynch. That weekend was a festival of Irish culture: in addition to the prize-giving at the end of a roundtable with the writers, several events were held-a concert of Irish music, an Irish dance class and Irish whiskey tasting... The four writers were delighted to meet their French readers, but also to enjoy good food and wine, or to visit French painter Claude Monet's house and gardens and the Museum of Impressionism in the nearby village of Giverny.

This event gave me the opportunity to interview four authors who are representative of a new generation of Irish writers: two men and two women, aged 
around 40, who have just written their first or second novels. I was interested in questioning them about Irish culture and heritage, the books that influenced their writing, those they are reading, but also their own work, the use they make of their artistic licence, and the way they perceive their recent status as men and women of letters. This paper reports the informal conversation we had together. To know more about each of them, let us start with a short biography of the writer and a brief synopsis of the listed novel.

\section{Ciarán Collins}

Ciarán Collins is an Irish author who was born in Cork in 1977. He grew up in the village of Innishannon, Co Cork. He studied English and Irish at University College Cork and completed an MA in 2001, specialising in modern drama, especially the works of Tom Murphy, Brian Friel or Eugene O’Neill. Ciarán Collins has been a full-time secondary teacher of English and Irish since 2003. He lives in Kinsale with his wife and daughter. Ciarán Collins has written a couple of plays, a few short stories which will be published as a collection some day, and a short film script which was shortlisted for an award ${ }^{1}$. In 2013, Ciarán Collins wrote his first novel: The Gamal. For this book, Ciarán Collins won the Rooney Prize for Irish Literature. He was also one of the Newcomers of the Year at the Irish Book Awards. The Gamal received wide critical acclaim: it was praised by Edna O’Brien, Colum McCann, John Boyne or David Vann.

A gamal is a retard, a moron, a simpleton. It is from an Irish word, gamalog. In this case, the gamal is Charlie McCarthy, 25, the narrator of the novel. Reckoned to be on the autistic spectrum, Charlie is always standing or sitting apart, so as to watch others and listen to them, particularly a bunch of peers living in Ballyronan, a village of County Cork. This position makes him the witness of a tragedy caused by these individuals whose malicious intents bring about the deaths of his only friends, Sinead and James. After being exposed to the traumas of rape, suicide and murder, Charlie suffers from Post-Traumatic Stress Disorder: he lies on his bed for two years and listens to pop-rock music at full blast. In the wake of this long period of isolation, he is encouraged by his shrink, Doctor Quinn, to narrate his story and type one thousand words a day as part of a writing therapy. In this case, writing is not only telling a story, but also expressing emotions in order to recover from a bout of depression. Yet, writing so many words everyday is torture for Charlie, all the more so as, as he says himself, he is not a writer, but only a gamal...

1. See the author's official website : [http://www.Ciaráncollinsauthor.com/index.html]. 


\section{Mary Costello}

Mary Costello is originally from Galway but lives in Dublin. Her stories have been published in New Irish Writing, The Stinging Fly and in several anthologies including Town and Country - New Irish Short Stories (Faber and Faber) edited by Kevin Barry. She taught for many years. Her first book, a collection of short stories entitled The China Factory, was published in 2012 by Stinging Fly Press and was nominated for the Guardian First Book Award and the Irish Books Award. Mary Costello published her first novel, Academy Street, in $2014 \quad 2$.

In Academy Street, we first meet Tess Lohan in the 1940s, on the family farm in Ireland, dazedly mourning her mother, who has died of TB. Tess is so young that she barely knows how or why to grieve; Costello evokes the child's fantasies and confusions - she thinks the hearse will return with her mother in the front seat, smiling, "a terrible mistake put right." This evocation of the child's confusions shades into a heavier melancholy as she and her siblings drift apart. Costello moves with a light step across the years, and we are soon on Academy Street in New York City, where Tess rents an apartment with another Irish nurse. For two women their age, there are many social opportunities, but Tess's childhood traumas have rendered her awkward and fearful around new people, and while she manages to connect with one man, their encounter ultimately plunges her into a more profound solitude. The beauty of her young son offers some relief, but the child soon grows up and grows distant; by early adulthood he has "locked his heart against her," and Tess is as alone as she has ever been.

\section{Michèle Forbes}

Michèle Forbes was born in Belfast, Northern Ireland and graduated in English and Psychology from Trinity College, Dublin. She worked as Script Reader for the Abbey Theatre in Dublin and subsequently began acting with the Abbey Theatre Company, touring worldwide with such productions as the award-winning 'The Great Hunger' and 'Dancing at Lughnasa'. Her film work includes 'Omagh', written by Paul Greengrass and Guy Hibbert and directed by Pete Travis, which opened the Human Rights Watch International Film Festival at the Lincoln Center in 2005 and for which she won Best Actress Monte Carlo and was nominated Best Actress at the Irish Film \& Television Awards. Other film work includes 'Inside I'm Dancing', 'The Playboys', 'Dorothy Mills'; her television work includes the BBC productions 'Best: his Mother's Son', 'Journey to Knock', 'Holby City', 'Loving Miss Hatto' and 'Jack Taylor'. Michèle's theatre

2. See website: [http://www.artscouncil.ie/Interviews/Literature/Mary-Costello/]. 
work also includes 'Footfalls' and 'Come and Go' for 'Beckett in the City', 'Too Late for Logic', 'No Escape', 'Amazing Grace' at the Abbey Theatre. She won both the Bryan MacMahon and the Michael MacLaverty Awards for her short stories ${ }^{3}$. She recently published her second novel_Edith \& Oliver (2017). Her first one, Ghost Moth, was one of the most acclaimed debut novels of 2014.

During the hot Irish summer of 1969, tensions rise in Belfast where Katherine Bedford, a former actress, and her husband George, a firefighter, struggle to keep buried secrets from destroying their marriage. Throughout the events which unfold, the bonds of family are tested and forgiveness is made possible through two parents' indomitable love for their children. An exploration of memory, childhood, illicit love, and loss, Ghost Moth portrays ordinary experiences as portals to rich internal landscapes: a summer fair held by children in a back-yard garden exposes the pangs and confusion of a first crush; an amateur theatre production of Bizet's Carmen hires a lonely tailor who puts so much careful attention into the creation of a costume for his lover that it's as if his desire for her can be seen sewn into the fabric. All the while, Northern Ireland moves to the brink of civil war. The lines between private anguish and public outrage disintegrate in this tale about a family_ and a country_ _ seeking freedom from ghosts of the past.

\section{Paul Lynch}

Paul Lynch was born in Limerick in 1977, grew up in Co Donegal, and lives in Dublin with his wife and daughter. He was the chief film critic of Ireland's Sunday Tribune newspaper from 2007 to 2011, when the newspaper folded. He has written for many Irish newspapers and has written regularly for The Sunday Times on film. Paul Lynch is the prize-winning author of The Black Snow (2014) and Red Sky in Morning (2013). His debut novel was published to critical acclaim on both sides of the Atlantic. It was a finalist for France's 'Prix du Meilleur Livre Étranger' and was nominated for the 'Prix du Premier Roman'. In the US, it was an Amazon.com Book of the Month and was featured on NPR's All Things Considered, where Lynch was hailed as "a lapidary young master". It was a book of the year in The Irish Times, The Toronto Star, the Irish Independent and the Sunday Business Post ${ }^{4}$.

The story of Red Sky in Morning starts in Spring 1832, in Co Donegal. Coll Coyle wakes to a blood dawn and a day he does not want to face. The young father stands to lose everything on account of the cruel intentions of his landowner's heedless son. Although reluctant, Coll sets out to confront his trouble.

3. See the writer's official website: [http://www.micheleforbesauthor.com/home/].

4. See the writer's official website: [www.paullynchwriter.com/]. 
And so begins his fall from the rain-soaked, cloud-swirling Eden, and a pursuit across the wild bog lands of Donegal. Behind him is John Faller-a man who has vowed to hunt Coll to the ends of the earth-in a pursuit that will stretch to an epic voyage across the Atlantic, and to greater tragedy in the new American frontier. Red Sky in Morning is a dark tale of oppression bathed in sparkling, unconstrained imagery. A compassionate and sensitive exploration of the merciless side of man and the indifference of nature, it is both a mesmerizing feat of imagination and a landmark piece of fiction.

$* * *$

B.C.: Welcome to the four of you, and thank you for accepting to answer my questions. Could you tell me first if writing is your only activity or if you have another job: do you have to share your time between writing and something else?

P.L.: No, I just do this. So I work most days. Writing a novel is a huge job. It's exhausting. There are two aspects in trying to actually write: produce writing that actually meets standard, but it is also just the idea of psychology that you have to keep yourself. You have to keep yourself fit for the job. You have to keep your selfbelief at a high level, otherwise you collapse with it. That's the big task.

M.F.: Well, my background is in theatre. I'm an actress, but primarily, now I'm writing, unless an acting project comes up that I'm really interested in, but otherwise I'm writing all the time.

C.C.: I wish I could be a full-time writer but I'm a full-time secondary teacher of English and Irish.

M.C.: I used to be a teacher, so I just gave up about six years ago when my first book came out. It was a collection of short stories, The China Factory, and I wrote most of those over ten or twenty years. I published a few stories when I was young, in my early twenties and they were shortlisted for awards, but then I got married when I was 23 and I was teaching full-time, so writing slipped a little bit into the margins of my life, but I kept writing and reading and I was into my forties when I sent out some stories and the publisher liked them and that's how my first book came about. So then I took a career break from teaching and I wrote my novel and that was well-received, thankfully, and published, and I'm working on my second novel now.

\section{B.C.: What is most difficult for you in writing?}

P.L.: Writing. There's a standard that has to be met, an ideal, and I'm not happy until the writing finds that place. Every day I'm tempted to reach for something almost impossible to try... 
M.C.: The most difficult thing in writing, I think, for me: it changes but right now, I suppose, it's self-belief. Sometimes, I have a lot of doubt: will I be able to do this? Sometimes I lack confidence. I read something I've written and I think 'it's so weak'... My eyes almost bleed with first drafts or second drafts I ever saw. I work hard to get it, to rewrite them, but I also feel that sometimes I might not deliver what is in my mind, and might not deliver the story. I don't really care about reviewers or publishers or agents or selling the book. My only allegiance is to the story and the characters. And I feel burdened with responsibility to bring that out of me as well as I can, and I can be very self-critical, and I don't show the work to anyone until I'm happy; so it's many, many drafts.

C.C.: I guess, for me, it's being ready to go to very dark places of the human heart and live there for a period of time. After writing The Gamal you know, I think I needed a break because if you're living in that world, in the intensity of it, in your imagination and in your heart for a very long time, to me, I think of it like Hamlet going off to see the ghost, you know... it's almost a place where most people don't go, because they have sense, you know... So it takes a bit of bravery to go to that place, but sometimes when you go there, you could bring back something magical for humanity. That's why I look at it. To me, it's a hard thing to do. That's a vocation. It's self-sacrifice. If you take writing seriously, you can know that's what you're getting into. That's the hardest thing. You have to say goodbye to the living world and hibernate away and just disappear from humanity, just to focus on your work.

M.F.: One of the most difficult things for me in writing is I have a family. My children now are 18 and 23, but when they are busy, I have time to write. But the process that I find most difficult is that I tend to overwrite. I need to be careful: I need when I'm editing to comb through the manuscript and try to cut it down because I tend to overwrite, so I'm learning...

\section{B.C.: Do you have a specific reader in mind when you write?}

P.L.: Myself. I write for myself. So when I have a book and it's nearly finished, I know that it's finished when I can read through it and forget that I've written it, and when I'm satisfied with what I'm reading in the text. The text has surpassed me and has become something else and so, when I'm reading it, because I have high standards when I read, so I look for this in my own work: if the work speaks to me in a way - a work would speak to me by another writer whom I admirethen I'm happy.

M.F.: No, I don't have a specific reader in mind when I write. I also don't necessarily have the self-consciousness of my own voice. I mean I've just published my second novel and it's an uneasy-learning process of finding your own voice. My life as an actress was always collaborative work, so your own voice can be 
deleted, diluted, and also, you're working with someone else's words. You're interpreting their words. So, through writing now, I'm discovering my solo voice, which is one of the main reasons why I wanted to write. What do I sound like alone and will that work? So I'm still discovering that. I'm not thinking of these known writers-James Joyce is not over my shoulder or Alice Munro, whom I love... I don't need to clear the room of everyone and just find what's here.

M.C.: I don't either, no. My partner is a writer as well, but I don't give it to him until it's very far. You know, recently, I finished a short story and I didn't give it to him until I was very happy. I couldn't. So I think doubt, self-doubt is my hardest problem.

C.C.: Hum, no. I think everybody who's properly literate should be able to appreciate the truth of good art, you know.

\section{B.C.: What are your literary influences?}

M.F.: I mentioned Alice Munro and I have written short stories as well, which I'm hoping to publish. She would definitely be one of my main influences, but I love, you know, the poetry of Seamus Heaney and I love Shakespeare also, through my work, and also playwrights have influenced me-Irish playwrights like Brian Friel, Tom Murphy... I worked with them. When their words sustain an actor night after night, you know, there's something very strong there. That would begin influence in my work. And I love-artists love reading themRichard Ford, I adore George Saunders, so yes, there would be voices that I would turn to, to remind me of what I want to achieve.

M.C.: I suppose one cannot leave behind the Irish influences: I do love Joyce, I love McGahern, I love Edna O'Brien and Irish writers of the 60s, 70s, 80s onwards - very famous - but I suppose they're not necessarily Irish. I do love J. M. Coetzee: he's my favourite novelist. Everything he writes, he writes with such integrity and he investigates. You know, there's no shirking of the self; there's no escape from the truth with Coetzee. Some people think he's quite cold, but he dives into the lives of all creatures, not just humans, but animals as well, and he gives them their due, you know. He writes older women very, very well: Elizabeth Curren in Age of Iron, Elizabeth Costello (Elizabeth Costello)—she wears my name...- and he writes them with such depth and unforgivingly sometimes, on the contrary. What they are, really, you know, they don't avoid anything, they cogitate on life and death and the soul. The number of times Coetzee uses the word 'soul' in his fiction is amazing. Once Elizabeth Costello is at the gates of heaven, being asked to write a report of her life and she keeps going back saying 'I was a writer, that's all I was, there's nothing else', she's not allowed to be admitted, and then she goes back and says the one thing that she remembers of all her life is when the mud-flaps in Australia dried up and the frogs were parched and dehy- 
drated, and that pained her deeply. And that is what Coetzee does: in a moment he can bring us back to the innate suffering of humanity and animal creatures in a very beautiful moment. I also love Marilynne Robinson, the American writer; she writes about transient life, poor lives: the homeless, the migrant workers of the 1930s, and she also gives them very human dignity, no matter how poor they are, they cannot be robbed of their human spirit and she gives them their due. She writes about philosophical things and religious things, but she doesn't let God or religion or theologies off the hook: she questions them. She writes beautifully about these people who have never heard of God or who are poor, you know. She writes beautifully about childhood as well. Two of her characters-Lila and Silvian Ruthie-beautifully evoke childhood. And, I love Camus, I love his nonfiction. I love his essays on Algeria where he was growing up.

\section{B.C.: Do you feel indebted to the Irish writers of the past?}

C.C.: Hum, I feel indebted to Joyce in terms of the novel, certainly, and the way I'd approach the novel. I feel very hugely indebted to Joyce, but I think I'd feel that way about him if I was English or French or American, you know...

\section{B.C.: AE is quoted in the epigraph of Red Sky...}

P.L.: There is a dash for sure and I think the best way to describe that is an inheritance of freedom. That writers who, like Joyce-Beckett is a more tricky conversation to have because he ran away from Hiberno-English-but writersYeats, Joyce and others-deliberately embraced the strain, the idiom of English that we speak, which is called Hiberno-English, that there are slightly different grammatical structures, there are reversals in sentences, there's a music in the sentences in the way we speak English and these writers seized that and used it for their own artistic freedom in a way that English writers, British writers don't. There's a lot of conservatism in the style of English writing, of course not all of it, there are some really great stylists, but Irish writers in particular seem to just take it as a given that they can use a bit of the freedom they like and that is an inheritance and I have taken that and I try to do my own thing in English. I try to create my own sound.

\section{B.C.: How far is your fiction influenced by Irish writers?}

P.L.: I'm not very much influenced by Irish writers. Most of the writers who influence me would be American and writers in translation, writers like Faulkner and Cormac McCarthy. 


\section{B.C.: In Red Sky in Morning, the story is told by different narrators, which is reminiscent of Faulkner's technique indeed: are such connections delibe- rate?}

P.L.: Yeah. I mean, Cormac McCarthy said the inescapable factor was that books were made from other books, and so we are what we read. I'm what I've read. There's something in the sensibility of writers like Faulkner and Cormac McCarthy that speaks to me very deeply to parts of my own sensibility, but you know there are other writers as well that I'm as much interested in: Mexican writers or Portuguese writers like Saramago... And perhaps their influence is less obvious in a book like Red Sky in Morning because I wrote that book seven years ago, I finished that seven years ago-I was 33 or 34 then.

\section{B.C.: What is your opinion, Ciaran?}

C.C.: Connections are not always deliberate. So, yeah, I know that without Shakespeare, without Joyce, even probably without the work of Bob Dylan, my novel wouldn't have been created in the way that it is. So, of course, there's such a huge part of my consciousness that certainly... I couldn't imagine being alive without them having lived, if you know what I mean, you know? So, anything that I write will always be indebted to them, I think.

\section{B.C.: The beginning of Academy Street reminded me of John McGahern's} fiction, with the mother's death and the father's bad temper in the Irish 1940s. Is there something deliberate here, Mary?

M.C.: I suppose everything that one reads influences us. We take it all in and it affects everything we write but that particular story in general, the story of my novel, has a family connection: my own mother grew up in the west of Ireland in a big old house just like Easterfield. I modeled, in the story, Easterfield and her family home. It wasn't called Easterfield. I fictionalized it, and her family bought that old house and farm in the early $20^{\text {th }}$ century. When my mother was three, she lost her mother who died suddenly of pneumonia, and the older sisters were away in boarding-schools at the time. They were taken out to mind the little ones. So when I was very young, I roved in the country and the farm. I was very close to my mother. I still am. She's in her late 70s, but I was very close to her in the way that some children often are. It's like being in love with your mother. I adore her and went everywhere with her, and I had brothers and sisters but, at some point, early on, I learned that she had lost her mother when she was a little girl and I would look at her and say 'You had no mother?' It used to fill me with sadness to think that she was deprived of what I had. I couldn't imagine... what a terrible fate not to have a mother like I had, and then when I got older and, you know, knew more about the family and everything, it 
struck me, when I became an adult, how catastrophic the death of a parent is in a family-especially a mother-and how it can change the whole trajectory of that family, because my mother went to secondary school, but she didn't go to university. Her sisters would have been destined for university because they were in boarding-schools; their friends became teachers and doctors and everything, but they didn't. They came out of school to mind the little ones and got married locally and I thought about how different everything could be and even my life, you know, if my mother had gone to university, how different down the generations, how one moment in fate, one catastrophic moment can change the trajectory of a whole family. So the childhood of Tess in the novel is modeled quite closely on my mother: this is rural Ireland in the 1940s. Ireland was quite poor in those days, even though, in the story, they have a good farm and a big house, but things are still quite backwards and the father is strict and Tess is hyper alert to the world. She's one of those children whose gap between perception and imagination is ajar. I think it is in all children, that's why we're alert to the world. You're close to animals when you're a child. You can almost hear the grass growing, that's what I think of them, and we meet Tess as a child at the opening, she's 7 , her mother has just died, but her personality is really formed largely at that point. It's not her mother's death that makes her fit for an adult really, and makes her sense of a child. This is her nature; this is her inborn nature. She was born like this.

\section{B.C.: Likewise, Ghost Moth is reminiscent of John McGahern's fiction... \\ M.F.: Oh, really? Oh yes...!}

\section{B.C.: ... a woman of the Irish countryside suffers from cancer and finally dies at the end of the book. Is such a connection deliberate?}

M.F.: No, it wouldn't be. And I'm thinking Ghost Moth really was a personal journey. The two time-frames come from a very personal thing. I grew up in Northern Ireland. The time-frame begins in 1969. And the character of the young girl is 9 then. I'm writing from her point of view, primarily to describe that world on the brink of what we now know as the Troubles, and the previous going back twenty years. The story within the family is added too, you know, and I thought 'I'm going to use that'. So it was a personal journey and I wasn't necessarily referring to other stories or other writers.

\section{B.C.: What about the literary references in The Gamal?}

C.C.: I knew exactly the story I was going to tell, and I knew how I was going to tell it. And I guess I would have assumed that things that were big in my consciousness would feature, you know-Bob Dylan or Joyce or any of the artists... Shakespeare, obviously... 


\section{B.C.: You quote the Bible too...}

C.C.: Yes, of course! You grow up in Ireland, so I think that's certainly unavoidable if, in a Catholic world, Christianity features in how you think, unavoidably, yes.

\section{B.C.: Academy Street quotes Albert Camus in the epigraph, but also the} Gospel; it refers to Joyce and Celtic legends... Mary, did you choose to quote or refer to a specific text? How does it work?

M.C.: They very much arrived in an organic fashion as I was writing. I'm a big fan of Camus. I love that quote in Camus and it suited. I didn't have that epigraph at the beginning, you know, by the time I'd written the novel. It became evident that it was very much suited to Tess- "In the depths of the winter, I finally learned that there lay in me an unconquerable summer"-and even in Tess's tragic life, I think she comes out with hope and she goes forwards, putting one foot in front of the other, because her heart is enlarged. She has known great tragedy, but she has also known great love and lived a full life. So her consciousness has been expanded. Her heart has been enlarged. Nothing is ever wasted. If I met Tess now, I think she would say "nothing is wasted". You live a long, full life, embrace it all and you learn and grow, and your heart is enlarged, but as regards texts, no... I'm interested in not so much religious things, but things that allow us to imagine the divine or the numinous or something like paradise. In a way, Tess is always longing for home; she has a great longing to go back to Ireland, but it's not just a physical home she's reaching for. It's a metaphysical home. She's longing to belong and it's almost like she's reaching, try to put something on higher and higher note, something numinous, sublime, maybe divine. Some people get that: that's our human urges. We're always reaching towards something that gives us meaning. For some people, it's art, it's love, it's God, they find it in those areas. Tess finds glimpses in the mass, she finds glimpses in her poetry; she's reading texts, glimpses in books. She gets a glimpse of it, constantly. She has her little epiphanies, her moments of glory, and I think the religious texts that I quote, the bits of poetry I quote fitted as I came onto a piece of writing with Tess. They automatically fit in for instance in the mass, the requiem mass, and the music soars to her. Church music is beautiful, profound, if you're bereaved or you're in love, those things touch the soul and Tess has a susceptible soul to those things.

\section{B.C.: "St Matthew Passion" by Johann Sebastian Bach, particularly...}

M.C.: Yes indeed, St Matthew Passion. All of those things return. She's a noneducated girl largely, but that doesn't mean she cannot be reached. 


\section{B.C.: Before writing your book, did you choose who you were going to quote, refer to or allude to, Michèle?}

M.F.: I don't think. That is not my style. My instinct is an emotional one and what I think is very important as well, and it's a feminine voice. I mean I'm quoting a lot of people, apart from Alice Munro, but when I was at the university, and also at school, a lot of the voices I would hear were in literature and poetry and playwriting. So this is my way of digging deep and expressing from a feminine point of view.

\section{B.C.: Feminine and Irish? Does it make sense for you to be considered as an Irish writer?}

M.F.: That's a very interesting question, because I feel the whole idea of the Irish identity is often about re-defining yourself through another language which is English, but for me, from the North of Ireland, my connection with the Irish language was nothing. I didn't have any connection with the Irish language. So, primarily, English is the place where I stand and the language that I use. So I didn't see myself within an Irish tradition necessarily. There was no selfconsciousness of that.

\section{B.C.: Would you define yourself as an Irish writer?}

P.L.: It's inescapable, isn't it? It's a problem, it's a classic problem for all writers, you know. Writers write from within a culture, they write from within a language and the language is the culture; the language is inhabited, the language weighs down on history. You cannot escape these things. So you choose the languagethe writer and his language. It's loaded with that. At the same time, I see myself just as a writer. I'm not really interested in Irish concerns. You know some nooks are deeply Irish. I write about universals. I'm interested in universal truths and human truths. The only thing I think about when I write is trying to get close to some idea, some metaphysical, psychological aspect of what it is to be alive, the problem of living, what it is to be alive. This is a universal problem, the same in every culture: what is being alive on earth? That, for me, is what I'm interested in, but books come out of the culture I've grown up in...

C.C.: It's not an easy one for me to answer... I know that it's a commonly used idea that there's a type of writer from Ireland that I would certainly think in terms of my own reading... If I was to spend most of my time reading, Joyce would be up there. Shakespeare would be up there. Then we might have Eugene O'Neill and lots of American writers, some French. John McGahern would feature. Edna O'Brien, ok. So well, it's part of who I am, I think, where I live... In terms of my own writing or art, I don't see myself as needing to fit into any 
notion of what an Irish writer is. I think writing is about humanity and all valid art for me can be approached by anybody, anywhere in the world, because they feel.

\section{B.C.: How far does Ireland influence your fiction?}

M.C.: I was born there. I was born in the West of Ireland, so I am Irish. It's inevitable that the language, the cadence, the music of the language comes out in me. It's who I am. I'm of the ground, I'm of the earth there. So, of course, one's family heritage first speaks, one's race and culture is laid down and imprinted on the DNA. So it's inevitable; it comes out of us. However, I don't necessarily regard myself or identify myself as an Irish writer. I'm a writer first; I'm a woman; I'm Irish. But that just happens chance. I think if I had grown up in Russia, America, I might be a writer too, and I think it's one's own sensibility that's the dominant factor in becoming a writer. It's one's inner landscape rather than the landscape around them that determines the way they write. I think for me, most of my characters are rather introverted and, you know, they tend to live quiet, inner lives.

\section{B.C.: They also feel guilty because of sex...}

M.C.: Yes. They live lives of trepidation in many regards and introverted look inwards. They get their energy from within. That doesn't mean they're not active and living very turbulent and interesting lives just because they're turned inwards... So I don't ever consider myself that I have an Irish voice in the sense that I feel obliged to comment on Irish society and traditions or mores, but it's inevitable. It's there in me. It's laid down on my DNA and Irish history, whether we like it or not, you know, we lost our land, let's say-and I'm not at all political-but we lost our land, we lost our language, so over years and generations, that must leave a mark on the Irish psyche. There must be a wound, a psychic wound there. Irish writers are often told they have a lonely voice, that they are very dark and very sad, and maybe that's how it manifests, and maybe it will take many more generations before we're daring, innovative, brash and extraverted.

\section{B.C.: What about Ghost Moth, Michèle? The Irish Troubles are in the background of the plot.}

M.F.: Yeah, yeah... That was important for me. The characters in the book, Catherine and George Bedford, are coming from Catholic and Protestant sides and seem to be reflecting my own family. They're like hybrid people who don't follow the edicts of a religion, but they live in a society which defines them solely by their religion and I found that very difficult when I was growing up, because we had two sides: the Protestant and Catholic sides were within the family. We knew the two traditions. So, to be defined as one or the other I found that very 
problematic. So it's kind of like a cognitive distance and you're gonna fold in those two ideas and I think Ghost Moth was part of that process of trying to see not necessarily where I fitted in, but just trying to give a voice to people in the margins of that society.

\section{B.C.: The plot of Red Sky in Morning takes place in the $1^{\text {th }}$ century: Paul, why are you so interested in that period?}

P.L.: Well, writers often say: "Oh I had this in mind" or "I had that in mind". I don't work that way, you know. The work comes to me intuitively and there are a whole of reasons why I wrote the book. Initially, it was the story of colons and Americans, and it created very powerfully within me. This moment in history was silenced. These people didn't make it; they were the immigrants who didn't succeed. So their voices were silenced and they were erased by history and then their story emerged. They were buried in a mass grave and nobody knew about it, nobody knew where they were, nobody knew it existed and then it emerged that perhaps they were murdered and so suddenly a door in history opened up, allowing these people to be heard again. I wanted to speak for them. I could hear something that used to be spoken. I grew up in that area where they came from. So I felt very powerful... I'm very interested in a form of using the past to distil human truth. If we write in the present moment, a lot of writers make the mistake of trying to describe the present moment. They want to describe what it is like to be alive now and I think that's too close to journalism for my taste. I'm interested in removing all the clutter and debris that is modern life and creating situations where we get very close to truth and however that may be about what it is to be a human being. And so when I write about the past, all of this stuff disappears and I can get closer and closer to these problems, so that's one of the useful things for me.

\section{B.C.: Are darkness and violence in the story inevitable? \\ P.L.: Did you notice that life is dark?}

\section{B.C.: You mean everybody has to make do with violence anyway?}

P.L.: Life is violent, you know. It's dark. We all die. This is inevitability... And we just choose to not think about it for most of our lives, but if you're a writer, you think about this and you confront it. Writing is perhaps a daily confrontation with these kinds of truths, you know, struggling with them. This is why writers can't cope at some level with facts of what life is and, you know, Rilke said: "beauty is nothing but the beginning of terror". I like that because it reminds us of death, and so, I try to make my books as beautiful as possible. I try to startle people with how beautiful they are because life is also very beautiful, and beauty 
can slow life down and be wonderful. That's an important thing but, at the same time, the more beautiful something is, the more we understand the road of terror because we know that beauty cannot last.

\section{B.C.: Is being an Irish writer today easier than in the past?}

P.L.: I don't know. The truth is that every writer thinks that the period preceding him was a glorious period for literature and that writers had better, higher quality of respect, of being reviewed in a more intelligent and profound way than writers feel that they have now. They think that literature was taken more seriously but, you know, I was reading the other day that Pope considered literature was not so well received in his own days, and I think that the mistake writers make is that, when we look back, the land and history remove all of this stuff and we just see the great names-we see Joyce... Whatever the country, you see the great writers in a sort of great proximity to each other and it looks like something magical was happening, but the truth is that they were just as miserable and unread and poorly paid as the rest of us are now, and I don't think anything really changed.

\section{B.C.: What's your opinion about today's Irish fiction?}

C.C.: I think it's wonderful. I'm very excited to be here in France with other Irish writers, but I think I'm more excited to be here in France with some wonderful writers. The fact that they're Irish is, I think, for people who may not be from Ireland to judge, because it's very hard for me, as an Irish person, to know if we, as a group, are bringing something particular to the feast, if you know what I mean.

M.F.: I think today's Irish fiction is wonderful too. There's a whole wave of new writers. It's really heartening and it's vibrant, you know. You have writers like Claire Keegan and Claire Kilroy and, of course, Anne Enright. It's just this great muscle in the writing and it's very diverse, as well. It's not kind of what Ireland is and what a woman in Ireland is. It's looking outward all the time and it's also playing with form. That's great!

\section{B.C.: Edna O'Brien and Jennifer Johnston were pioneers in that field...}

M.F.: Completely, completely: Edna O’Brien, absolutely right the way down. People like Maeve Binchy as well, who might not be considered in the same sort of tradition as Edna O'Brien but... what a wonderful story teller! They were the pioneers, absolutely, you know, and they have inspired generations after generations of young writers. 


\section{B.C.: Your books would have been banned if they had been written fifty years ago... \\ M.F.: I think so, yes...! \\ P.L.: Yes, exactly!}

\section{B.C.: Do you feel free to write whatever you want today?}

M.F.: Yes I do, actually. I do.

P.L.: Yes, of course! In fact, I would say that there is complete indifference...

C.C.: I do, yeah. You know, I'm a teacher in a Catholic school, but I think as an artist, as a writer, everything should get published. I have stories that I've written at home, that I wrote for myself, and some day, I may publish them, everything I write, because I feel that it's the right thing to do, that I should for myself. The thing I'm most pleased about with The Gamal is that I followed the vision I had. As it is published, it remains exactly the same as the initial draft that I had sent off, in terms of the first fifty pages that I sent off; because I came across it recently and nothing has changed, which is nice. It means that I haven't been corrupted by any notion of what the reader might want...

M.C.: I feel free to write whatever I want today. I do. Towards the end of my book, there is a huge catastrophe in Tess's life, a great loss, and some interviewers said to me: how did you feel Tess has lived in America all her life and the great signature events of American life-Vietnam, JFK, 9/11—are mentioned in the book, they do have a bearing on her life, and some interviewers said 'how did you feel as an Irish woman about owning a large American event like 9/11 or Kennedy's death? How do you feel about getting permission to own that?' And I said I considered those very much global events and that the outpouring of grief that happened at 9/11 was felt by the whole world, including Irish people and a lot of Irish Americans. A lot of American people are Irish; it's an international society, so I didn't feel that it was owned by America alone, nor did I feel I wasn't entitled to write about it, and because the imagination doesn't recognize international borders surely and if I in any way turned down that story just because I was sensitive to politics, I would be self-censoring and I would not be a writer. I would not self censor, I would not set out to hurt people either. I would write what the story demands, I would write only what the story demands, and I won't hold back or censor and damage the integrity of the story. I don't want to hurt anyone either, but I think it's a difficult one for some writers, but all one can do is what one's own conscience allows.

\section{B.C.: Do you consider that anything can be written today?}

M.F.: Hum, I do. I think the job of a writer is to embrace that, no matter how difficult that might be. You know, you're not writing to please other people. You're 
writing for yourself and also, you're commenting on your own sense of existence in your society, so, yeah, that means that can be a very tricky question because we're very sensitive now to cause an offence, but that keeps pushing things down. So we need to be free to say what we really feel.

P.L.: Anything can be written, yeah. There's no such thing as outrage any more, but there is possibly an argument that despite what I was saying to you, that we are living a time with enormous acceleration and change, technology has changed; it's actually rewiring our brain toward distraction and people are more distracted now and, you know, people find it hard to read novels. And I look on the bus, I look on the train and nobody's reading books anymore and that has changed because people were reading books in the past. I think what happens is people perhaps, because they're not reading books now, the reading muscle has weakened and so, they're less able to read challenging books now and so they prefer to read fiction, it's much more comfortable for them. In the past, there was a large work of literature that was being talked about. People would make an attempt to read it. Now I think people don't really bother.

\section{B.C.: What about yourselves as readers: what are you reading now?}

C.C.: Right now, on the plane, I brought over a collection of essays on Eugene O'Neill. That's a very old book. I read some critical writing as well, just to learn more about art, probably more than anything else, and where the ideas of their work would have come from, and the things that are going on in the world, at the time that might influence how they work, how did they join that...

P.L.: I've just finished Beckett actually. I was reading some Beckett, just for fun. I was reading some Marina Carr: she’s extraordinary.

\section{B.C.: What did you read by Beckett: his novels or plays?}

P.L.: I read Endgame, reread it. I admire greatly how he abandoned the heritage of the luggage of language and wrote in French to escape all of this stuff. So he could get closer in his way to metaphysical truths. I'm reading Alice Oswald's new book of poetry, Falling Awake. She's an incredible writer. At the moment, I'm reading a lot of poetry, possibly because redrafting a work of poetry has certain standards. I think it's useful when, redrafting your fiction, you can borrow from something like poetry. It reminds you that there's a standard of precision.

\section{B.C.: If you wrote an essay or a nonfiction book, what would it be about?}

P.L.: I don't know. There is too much... There are too many facts in the world...

\section{B.C.: Mary, you wrote essays yourself, didn't you?}


M.C.: Yes, I've written a couple of essays about our most famous poet, Seamus Heaney, who died a few years ago. He grew up in rural Ireland, and several generations before him. His poetry and a lot of his stuff speak to me a lot because he's able to often integrate the personal with the universal and the mythical—often referring to Greek gods. I didn't study classical literature growing up, but I read Greek mythology and I love the way that everywhere we see signs: we see signs of the same patterns reappearing over and over, whether it is loss or love, or anger or fear or war. The same archetypes repeat themselves and poets especially can do that. They can bring the mythical into the everyday... how things suddenly flood in and give meaning to the moment...

\author{
B.C.: Well, thank you so much to all of you for 'playing the game'... \\ C.C.: You're welcome, Bertrand. \\ P.L.: Pleasure. \\ M.C.: Thank you. \\ M.F.: That's lovely, Bertrand. That's a nice warm-up for the conference...
}

After these interviews, authors were asked to sign their books. A round-table discussion was led by Christine Ferniot, a journalist for Lire and Télérama. And at the end of the day, after the deliberation, Ciarán Collins was delighted to hear that he was awarded the Prize 'Escapades 2017' for his novel, The Gamal. 